\title{
Front Matter: Volume 9458
}

, "Front Matter: Volume 9458," Proc. SPIE 9458, Cyber Sensing 2015, 945801 (29 May 2015); doi: 10.1117/12.2184329

SPIE. Event: SPIE Defense + Security, 2015, Baltimore, MD, United States 


\title{
PROCEEDINGS OF SPIE
}

\section{Cyber Sensing 2015}

\author{
Igor V. Ternovskiy \\ Peter Chin \\ Editors
}

\author{
21 April 2015 \\ Baltimore, Maryland, United States
}

Sponsored and Published by

SPIE 
The papers included in this volume were part of the technical conference cited on the cover and title page. Papers were selected and subject to review by the editors and conference program committee. Some conference presentations may not be available for publication. The papers published in these proceedings reflect the work and thoughts of the authors and are published herein as submitted. The publisher is not responsible for the validity of the information or for any outcomes resulting from reliance thereon.

Please use the following format to cite material from this book:

Author(s), "Title of Paper," in Cyber Sensing 2015, edited by Igor V. Ternovskiy, Peter Chin, Proceedings of SPIE Vol. 9458 (SPIE, Bellingham, WA, 2015) Article CID Number.

ISSN: 0277-786X

ISBN: 9781628415742

Published by

SPIE

P.O. Box 10, Bellingham, Washington 98227-0010 USA

Telephone +1 3606763290 (Pacific Time) · Fax +1 3606471445

SPIE.org

Copyright $@ 2015$, Society of Photo-Optical Instrumentation Engineers.

Copying of material in this book for internal or personal use, or for the internal or personal use of specific clients, beyond the fair use provisions granted by the U.S. Copyright Law is authorized by SPIE subject to payment of copying fees. The Transactional Reporting Service base fee for this volume is $\$ 18.00$ per article (or portion thereof), which should be paid directly to the Copyright Clearance Center (CCC), 222 Rosewood Drive, Danvers, MA 01923. Payment may also be made electronically through $\mathrm{CCC}$ Online at copyright.com. Other copying for republication, resale, advertising or promotion, or any form of systematic or multiple reproduction of any material in this book is prohibited except with permission in writing from the publisher. The CCC fee code is $0277-786 \mathrm{X} / 15 / \$ 18.00$.

Printed in the United States of America.

Publication of record for individual papers is online in the SPIE Digital Library.

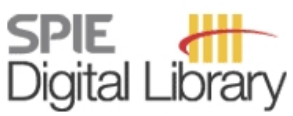

SPIEDigitalLibrary.org

Paper Numbering: Proceedings of SPIE follow an e-First publication model, with papers published first online and then in print. Papers are published as they are submitted and meet publication criteria. A unique citation identifier (CID) number is assigned to each article at the time of the first publication. Utilization of CIDs allows articles to be fully citable as soon as they are published online, and connects the same identifier to all online, print, and electronic versions of the publication. SPIE uses a six-digit CID article numbering system in which:

- The first four digits correspond to the SPIE volume number.

- The last two digits indicate publication order within the volume using a Base 36 numbering system employing both numerals and letters. These two-number sets start with 00, 01, 02, 03, 04, $05,06,07,08,09,0 A, 0 B \ldots 0 Z$, followed by 10-1Z, 20-2Z, etc.

The CID Number appears on each page of the manuscript. The complete citation is used on the first page, and an abbreviated version on subsequent pages. 


\title{
Contents
}

\author{
$\checkmark \quad$ Authors \\ vii Conference Committee
}

\section{SESSION 1 CYBER SENSING I}

945802 Improved image reconstruction from sub-apertures of circular spotlight SAR [9458-1]

945803 Testing simple deceptive honeypot tools [9458-2]

945804 A prototype forensic toolkit for industrial-control-systems incident response [9458-3]

\section{SESSION 2 SITUATION AWARENESS: JOINT SESSION WITH CONFERENCES 9458 AND 9464}

945806 Qualia centric hypothetical thinking: applications to vehicle tracking with the fusion of EO and SAR input data sources (Invited Paper) [9458-5]

945807 QuEST for malware type-classification [9458-6]

\section{SESSION 3 CYBER SENSING II}

945808 On a simulation study for reliable and secured smart grid communications [9458-7]

945809 Risk assessment by dynamic representation of vulnerability, exploitation, and impact [9458-8]

9458 0A ASN reputation system model [9458-9]

9458 OB Cybersecurity for aerospace autonomous systems [9458-10]

SESSION 4 CYBER SENSING III

9458 OF Network systems security analysis [9458-14]

$9458 \mathrm{OH} \quad$ Cyber warfare and electronic warfare integration in the operational environment of the future: cyber electronic warfare [9458-16] 
Proc. of SPIE Vol. $9458945801-4$

Downloaded From: https://www.spiedigitallibrary.org/conference-proceedings-of-spie on 26 Apr 2023 Terms of Use: https://www.spiedigitallibrary.org/terms-of-use 


\title{
Authors
}

Numbers in the index correspond to the last two digits of the six-digit citation identifier (CID) article numbering system used in Proceedings of SPIE. The first four digits reflect the volume number. Base 36 numbering is employed for the last two digits and indicates the order of articles within the volume. Numbers start with 00, 01, 02, 03, 04, 05, 06, 07, 08, 09, 0A, 0B...0Z, followed by 10-1Z, 20-2Z, etc.

\author{
Askin, Osman, $\mathrm{OH}$ \\ Avsever, Mustafa, $\mathrm{OH}$ \\ Cam, Hasan, 09 \\ Carr, Nickolas B., 04 \\ Culbertson, Jared, 06 \\ Dube, Thomas E., 07 \\ Erbacher, Robert F., OA \\ Grimaila, Michael R., 07 \\ Helmstetter, Anthony, 06 \\ Hutchinson, Steve, OA \\ Irmak, Riza, $\mathrm{OH}$ \\ Mallapuram, Sriharsha, 08 \\ Mills, Robert F., 07 \\ Moulema, Paul, 08 \\ Oxley, Mark E., 07 \\ Peterson, Gilbert L., 07 \\ Rogers, Steven K., 07 \\ Rowe, Neil C., 03, 04 \\ Straub, Jeremy, OB \\ Ternovskiy, Igor, 02, 06 \\ Vaughan, Sandra L., 07 \\ White, Jonathan, 06 \\ Yahyaoui, Aymen, 03 \\ Yilmaz, İsmail, OF \\ Yu, Wei, 08 \\ Yuan, Xiaohui, 02
}


Proc. of SPIE Vol. $9458945801-6$

Downloaded From: https://www.spiedigitallibrary.org/conference-proceedings-of-spie on 26 Apr 2023 Terms of Use: https://www.spiedigitallibrary.org/terms-of-use 


\title{
Conference Committee
}

\author{
Symposium Chair
}

Nils R. Sandell Jr., Strategic Technology Office, DARPA

(United States)

Symposium Co-chair

David A. Logan, BAE Systems (United States)

Conference Chairs

Igor V. Ternovskiy, Air Force Research Laboratory (United States)

Peter Chin, Draper Laboratory (United States) and Boston University (United States)

Conference Program Committee

Chad D. Heitzenrater, Air Force Research Laboratory (United States)

Tony C. Kim, Air Force Research Laboratory (United States)

\section{Session Chairs}

1 Cyber Sensing I

Igor V. Ternovskiy, Air Force Research Laboratory (United States)

Peter Chin, Draper Laboratory (United States) and Boston University (United States)

2 Situation Awareness: Joint Session with Conferences 9458 and 9464 Igor V. Ternovskiy, Air Force Research Laboratory (United States)

Tien Pham, U.S. Army Research Laboratory (United States)

3 Cyber Sensing II

Igor V. Ternovskiy, Air Force Research Laboratory (United States)

Peter Chin, Draper Laboratory (United States) and Boston University (United States)

4 Cyber Sensing III

Igor V. Ternovskiy, Air Force Research Laboratory (United States)

Peter Chin, Draper Laboratory (United States) and Boston University (United States) 
Proc. of SPIE Vol. $9458945801-8$

Downloaded From: https://www.spiedigitallibrary.org/conference-proceedings-of-spie on 26 Apr 2023 Terms of Use: https://www.spiedigitallibrary.org/terms-of-use 